\title{
Las izquierdas ante el Cordobazo: posiciones, debates y reorientaciones
}

\author{
Hernán Camarero \\ Instituto Ravignani - CONICET - Universidad de Buenos Aires - \\ Centro de Estudios Históricos de los Trabajadores y las Izquierdas (CEHTI), Argentina \\ hercamarero@gmail.com \\ Martin Mangiantini \\ Instituto Ravignani - CONICET - Universidad de Buenos Aires - \\ Centro de Estudios Históricos de los Trabajadores y las Izquierdas (CEHTI), Argentina \\ martinmangiantini@gmail.com
}

\section{RESUMEN:}

La extensa bibliografía que abordó el Cordobazo no se detuvo, o bien lo hizo parcialmente, en el modo las izquierdas se posicionaron ante este fenómeno. La propuesta del artículo es aportar en este sentido, a partir de un exhaustivo relevamiento de fuentes, con el objetivo de identificar las elaboraciones y posiciones neurálgicas de las diversas corrientes presentes en ese contexto. El texto explora la influencia que los sucesos cordobeses produjeron en cuanto a las prácticas y orientaciones político-programáticas de los partidos de izquierda, lo cual conduce a encarar los debates suscitados tanto en el interior de cada grupo como entre ellos.

Palabras clave: Izquierdas, Debates, Radicalización.

\section{Abstract:}

The extensive bibliography that studied the Cordobazo did not stop, or did it partially, in the ways in which the lefts were positioned before this phenomenon. The proposal of the article is to contribute in this sense, from an exhaustive survey of sources, with the objective of identifying the elaborations and neuralgic positions of the diverse currents present in that context. The text explores the influence that the events in Córdoba produced in terms of the political-programmatic practices and orientations of the left parties, as well as the debates aroused both within each group and between them.

KEYWORDS: Left parties, Controversial, Radicalization.

Existe cierto consenso historiográfico en establecer el año 1969 como uno de los puntos de inflexión en el devenir de la sociedad y la política argentina de la segunda mitad del siglo XX, en especial, si se atiende la dimensión del conflicto y de sus representaciones. Fue entonces cuando se produjo una serie de agudas protestas obreras y populares que pusieron en jaque el proyecto de largo plazo iniciado tan solo tres años atrás por el golpe de Estado encabezado por el general Juan Carlos Onganía. El Cordobazo, ocurrido a fines de mayo de ese año, fue el inicio de una crisis de dominación que trajo consigo una movilización autónoma de la sociedad superadora de sus mediadores naturales (O’Donnell, 1982; Portantiero, 1996; Cavarozzi, 2006). El país no fue igual desde aquellos días: la hegemonía quedó en cuestión.

El período abierto quedó configurado por la intensificación de la lucha de amplias capas de la clase trabajadora, la radicalización ideológica y un desbarajuste institucional que vio fracasar todas las estrategias de superación. Junto a la revuelta emergió una heterogeneidad de actores que pusieron en jaque la estatalidad vigente, la estructura económico-social y las configuraciones ideológicas y culturales dominantes. Organizaciones político-militares, partidos autodefinidos como revolucionarios, un sindicalismo clasista, el activismo estudiantil universitario y secundario, movimientos intelectuales, culturales y hasta religiosos 
coexistieron en una época marcada por la intensa participación y radicalización (James, 2003; Schneider, 2005; Brennan, 2015; Brennan \& Gordillo, 2008; Balvé et al., 2006). Como parte de este proceso, las distintas expresiones de la izquierda alcanzaron, en los años siguientes, ciertas posibilidades de reincidir en sus vínculos con la clase obrera, más allá de la mayoritaria adhesión de ésta al peronismo (Pozzi \& Schneider, 2000).

Es mucho lo que se ha indagado ya acerca del Cordobazo en sus múltiples planos de análisis empíricos, temáticos y conceptuales, y desde abordajes disciplinarios diversos (histórico, sociológico, politológico, cultural o discursivo). Como parte de ese examen, algunos estudios se refirieron parcial o específicamente a los modos en el que las izquierdas se posicionaron ante el proceso. Este estudio fue realizado hasta el momento de manera incompleta, dejando a algunas de las expresiones de la izquierda sin tratamiento, al mismo tiempo que se carecía de una consideración global y comparativa entre todas ellas. La propuesta de este artículo es aportar en este sentido, a partir de un exhaustivo relevamiento de fuentes, con el objetivo de identificar y auscultar ciertas elaboraciones y posiciones neurálgicas de aquellas corrientes políticas.

Las alusiones historiográficas a las izquierdas no cubrieron de manera uniforme y coherente todas las temporalidades necesarias de tener en cuenta. Aquí se pretende superar estas discontinuidades, apelando a un relevamiento cronológico más amplio. En función de ello, se investigan las caracterizaciones de las corrientes en tres etapas diferenciadas: en los prolegómenos del estallido de Mayo de 1969 (para pensar los modos bajo los cuales el Cordobazo se asimiló, o no, a sus perspectivas previas); en los momentos inmediatamente posteriores al hecho (a los efectos de evaluar el impacto inmediato generado en sus orientaciones) y, finalmente, los balances realizados una vez transcurrido un tiempo más largo, lo que permitió tomar mayor distancia a la luz de los sucesos posteriores. Asimismo, el trabajo se adentrará también en la influencia que el Cordobazo produjo en cuanto a las prácticas y orientaciones político-programáticas de los partidos de izquierda, lo cual conduce a encarar los debates experimentados tanto en el interior de cada grupo como entre ellos, alrededor de las formas de intervención, los modelos organizativos a desarrollar y el análisis del contexto político.

Como ocurrió con todos los contemporáneos al estallido cordobés, las izquierdas también fueron ganadas por la sorpresa ante el inesperado hecho histórico. Los grandes acontecimientos que producen virajes de la realidad suelen implicar una interrupción y desordenamiento de las argumentaciones y posturas en los actores que los viven. Por ello es necesario recrear las diferentes modulaciones y capturar las contradicciones de los discursos y acciones tal como se expresaron en las fuentes de época. De este modo, en este estudio se recurrió a un examen combinado de la documentación interna proveniente de los organismos de dirección de los agrupamientos (en donde puede verse más diáfanamente las precarias tentativas para explicar la novedad del proceso) junto con los materiales públicos (periódicos, folletos o ediciones varias), en donde las palabras debían renunciar a traslucir cualquier duda y adoptar un carácter afirmativo.

Referirse a las izquierdas en la realidad argentina de los años sesenta y setenta no es una tarea carente de discusiones en cuanto a los criterios elegidos para justificar la inclusión de determinados grupos en detrimento de otros. En este caso, se optó por una selección de seis alternativas que se justifica por la existencia de un denominador común: todas ellas compartieron, por un lado, la premisa de la necesidad de construir herramientas partidarias como el instrumento de sus estrategias políticas y, por otro lado, se autodefinieron dentro del paradigma del socialismo marxista (más allá de las respectivas filiaciones y disímiles tradiciones).

Dentro del campo de la denominada izquierda tradicional se considera al Partido Comunista (PC), organización que combinaba el diseño de una propuesta moderada de cuño democrático reformista y de frente popular, junto a sus apelaciones a la ideología marxista y la fidelidad a la Unión Soviética (Tortti, 1999; Tortti, 2014; Camarero, 2014; Bonvillani, 2015). También se analizan los dos grupos más importantes del trotskismo en ese entonces: el Partido Revolucionario de los Trabajadores - La Verdad (PRT - LV), continuador de una corriente reconocible desde los años cuarenta bajo la dirección de Nahuel Moreno (González, 1999; Mangiantini, 2018); y Política Obrera (PO), sigla conformada en 1964, como deriva del grupo Praxis (Coggiola, 2006). Asimismo, se abordan otras dos organizaciones: la surgida en 1967 
como una fractura centralmente estudiantil del PC, adoptando la denominación de PC - CNRR (Comité Nacional de Recuperación Revolucionaria), un año después con su nombre definitivo de Partido Comunista Revolucionario (PCR), y que tiempo después se convierte al maoísmo (Califa, 2015; Rupar, 2017); y Vanguardia Comunista (VC), formada en 1965 como un "partido marxista-leninista" que, en el marco de la polémica chino-soviética, se definió por los principios de Mao Tse Tung y buscó la aplicación de los mismos a la realidad argentina (Celentano, 2014; Soto, 2004). Finalmente, se incluyen los posicionamientos del Partido Revolucionario de los Trabajadores - El Combatiente (PRT - EC), vertiente escindida de la ruptura del PRT de 1968 convertida en una de las más importantes organizaciones político-militares (Pozzi, 2004; Weisz, 2004; Carnovale, 2011).

\section{Antes del Cordobazo}

La indagación debe comenzar con interrogantes alrededor de dos cuestiones, que se hallan imbricadas entre sí. ¿De qué modo, en los prolegómenos del estallido cordobés, las diversas organizaciones revolucionarias caracterizaban el devenir del onganiato y su estabilidad como proyecto? Vinculado a ello, vale preguntarse: ¿existió algún tipo de previsión en sus análisis que vislumbrara la crisis venidera y el ánimo general de los sujetos que protagonizarían los sucesos de mayo?

En los meses previos al Cordobazo hubo un incremento de conflictos laborales, cuyos reclamos recaían en la defensa de las condiciones de trabajo ante el aumento de la racionalización y los despidos. También ocurrieron acciones sindicales por aumentos salariales, tales como el trabajo a reglamento, los paros parciales o quites de colaboración. Este escenario daba cuenta del surgimiento de una nueva camada de militantes que trascendían las estructuras sindicales tradicionales y resurgían tras el ciclo de derrotas experimentadas al inicio del golpe (Gordillo, 1991; Schneider, 2005; Castillo \& Raimundo, 2012).

El Partido Comunista destacó la importancia de las protestas vividas en diversas provincias del interior del país. Desde los inicios de 1969 subrayó como un avance la vinculación cada vez mayor entre las luchas económicas y políticas extrayendo dos conclusiones. En primer lugar, que fueron las propias masas movilizadas las que impusieron, de hecho, la unidad de acción y forjaron un inicio de coordinación y entendimiento entre las tendencias de una CGT atomizada y, por otro lado, que el éxito de esos conflictos obedeció a su gestación en el seno del movimiento obrero y popular mediante la formación de comisiones coordinadoras en las fábricas, o bien, de embriones de articulación entre vecinos, estudiantes, obreros y fuerzas políticas, dando por tierra con la política de colaboración sindical propiciada por Onganía. Se analizaba que la mayor debilidad recaía en la desconexión entre sí de los numerosos conflictos ante la falta de un centro dirigente nacional ${ }^{1}$. En los momentos inmediatamente anteriores al estallido, el PC percibió la llegada de una nueva etapa en el "combate contra la dictadura" ante la irrupción de fuerzas que dictaminarían su crisis ${ }^{2}$.

Dentro del trotskismo, la conflictividad fue identificada por el PRT - LV como expresiones de un reanimamiento desarrollado desde las bases en los ámbitos fabriles con ciertos rasgos de "espontaneísmo" y “desorganización”, a partir de determinadas consignas reivindicatorias ${ }^{3}$. Este partido vislumbró la aparición de una nueva vanguardia obrera que ya había hecho una experiencia con sus direcciones burocratizadas y, por ende, comprendía la necesidad de desarrollar metodologías más contundentes, extender los conflictos y coronar las luchas sindicales con un cambio político. No obstante, este fenómeno no era representativo del ánimo de la clase en general lo que impedía transformarlo en la nueva dirección de las luchas ${ }^{4}$.

En similar línea, Política Obrera destacaba la politización percibida en algunas plantas del país, como la industria automotriz cordobesa, advirtiendo que allí se tomaba conciencia del papel y los métodos de las direcciones sindicales burocratizadas, al tiempo que se generaba una ligazón con las luchas estudiantiles. En consonancia con el PRT - LV, subrayó que el salto de la lucha obrera contra el régimen militar encontraba 
como debilidad central la ausencia de una dirección revolucionaria del movimiento obrero y el vacío que la burocracia había realizado ante el reclamo de paro nacional en solidaridad con Córdoba ${ }^{5}$. El papel de las direcciones sindicales fue también mencionado por el PRT - EC, al afirmar que éstas habían perdido la posibilidad de responder a las necesidades de sus afiliados a partir de la "demagogia de las conquistas". No obstante, aseveraba que el movimiento obrero no constituía un peligro para la estabilidad del régimen, sino que su debilidad provendría de las tensiones dentro de los sectores dominantes ${ }^{6}$.

Los conflictos acaecidos antes del Cordobazo tuvieron su impacto. Fue Política Obrera quien destacó con mayor énfasis el proceso de Córdoba como anticipo de la explosión por llegar. Identificaba un fenómeno particular de maduración política de la clase obrera visualizado, sobre todo, en las huelgas de las plantas automotrices ${ }^{7}$. La conflictividad previa, no solo cordobesa, fue vista también por el PRT - LV como un giro importante en el desarrollo de las movilizaciones contra la dictadura, llamando a las vertientes de la CGT a impulsar un paro conjunto al que también se volcara la FUA y el movimiento estudiantil ${ }^{8}$.

Desde finales de 1968, el PCR destacaba la existencia de luchas parciales, a las que caracterizó como un "polvorín" de descontento popular, necesario de hacer estallar para romper el cerco de la dictadura: se imponía la premisa de establecer un gobierno popular revolucionario a partir de la acción de los obreros, campesinos, estudiantes e intelectuales y construir un partido comunista fuerte ${ }^{9}$. En tanto, el número anterior al Cordobazo de No transar, de Vanguardia Comunista, reflejó la conflictividad contra el gobierno, sin vislumbrar en el análisis la llegada de un estallido como el que se avecinaba. Destacó sucesos de Tucumán y Santa Fe sin darle primacía a Córdoba ${ }^{10}$.

Si bien el movimiento obrero poseía centralidad en los análisis vertidos por las izquierdas, las referencias a otros sujetos sociales no se hallaron ausentes. Para el PCR, existía un conjunto de capas y clases sociales más allá del proletariado (como el semi-proletariado urbano y rural, el campesinado pobre y medio, las capas medias y urbanas y la mayoría de la intelectualidad y el estudiantado) proclives al cambio radical ${ }^{11}$. Vanguardia Comunista también daba cuenta de una amplitud al identificar que, desde los obreros hasta los empleados, campesinos pobres y medios, intelectuales revolucionarios y la pequeña burguesía urbana eran actores factibles de integrar a una "revolución nacional, democrática y popular" 12 .

El trotskismo ponderó la figura del estudiantado sin que ello implicara la puesta en práctica de una acción desligada de la clase obrera. Así, el PRT - LV impulsó la idea de desarrollar métodos de autodefensa ante la represión estatal, instando a que desde los centros de estudiantes y universidades se organizaran piquetes para la movilización anti-dictatorial ${ }^{13}$. Política Obrera propuso la conformación de comités obreros de resistencia, inter-fabriles y comités conjuntos obrero-estudiantiles para la articulación de las luchas y el enfrentamiento a la represión en la perspectiva de un paro obrero-estudiantil nacional ${ }^{14}$.

Destacando, por su parte, el papel del estudiantado, el campesinado y una pequeña-burguesía no atada al capital extranjero, el PC sostuvo la necesidad de unificación de las diversas fuerzas anti-dictatoriales en un Centro Coordinador que se nucleara bajo un programa de acuerdos mínimos conformándose, a su vez, comisiones coordinadoras en fábricas, ámbitos educativos, barrios y concentraciones campesinas ${ }^{15}$. Sus planteos encontraban una base de sustento proveniente de la estrategia y proyección del Frente Democrático Nacional (Camarero, 2014). En su XIII Congreso Nacional, de marzo de 1969, reafirmó que la contradicción principal en la Argentina era aquella protagonizada por las fuerzas productivas (obreros, empleados, campesinos y burguesía nacional) que pugnaban por su desarrollo y las relaciones de producción, identificadas en la oligarquía terrateniente, el gran capital internacional y los monopolios extranjeros, que las detenían. Así, resultaba necesaria la unidad en un frente de aquellas oposiciones a la dictadura que desembocara en un gobierno de coalición democrática y en la posterior convocatoria a una Asamblea Constituyente ${ }^{16}$.

Se desprende de los diversos análisis de las izquierdas que el escenario se hallaba abierto a disímiles posibilidades. Entre las perspectivas, se presagió la posible consolidación de la dictadura si las luchas populares 
no lograban revertir ese proceso ${ }^{17}$, la profundización de los enfrentamientos entre diversos componentes del gobierno $^{18}$, e incluso, la posibilidad de una salida ordenada mediante la convocatoria electoral ${ }^{19}$.

Los prolegómenos del Cordobazo fueron también un momento en el que estas organizaciones definieron sus estrategias de intervención. Hubo ciertos debates, más o menos directos, entre los grupos y, al mismo tiempo, una serie de polémicas y tensiones internas dentro de ellos alrededor de la política a desarrollar. La discusión estratégica que cruzaba al conjunto de las organizaciones radicaba en la vía para la transformación revolucionaria de la sociedad. Se trató de un período surcado por posicionamientos en favor de la alternativa insurreccional en oposición a aquellos que propugnaban las acciones armadas como paso previo al camino de la insurrección, como así también de posturas conciliadoras de ambas nociones.

Vanguardia Comunista esgrimió la tesis maoísta que le permitía enfatizar los rasgos feudales y de atraso de la Argentina, por lo que el proceso revolucionario se libraría del campo a las ciudades. En 1968 caracterizó al país como "neocolonial y dependiente del imperialismo" con predominio de relaciones capitalistas y subsistencia de rasgos pre-capitalistas. Ello daba lugar a "zonas críticas" en el interior, factibles de ser utilizadas como eslabones débiles en donde podía cesar la dominación imperialista mediante la Guerra Popular Prolongada cuyo teatro principal de operaciones sería el campo. El deber del proletariado sería organizar y movilizar al campesinado para concentrar las fuerzas en el ataque a los terratenientes y monopolios imperialistas ${ }^{20}$.

El PCR presentaba a la Argentina como un país capitalista deformado por rémoras pre-capitalistas subsistentes en el campo. No obstante, aseveró que la vía para el triunfo revolucionario sería la insurrección armada sostenida por todo el pueblo pero cuyo papel de dirección recaería en la clase obrera. Esta debía dominar todas las formas de lucha y saber combinarlas o pasar de una a otra según las circunstancias. El PCR se diferenció tanto de la tendencia "foquista" por negar el rol de un partido revolucionario como del método de la Guerra Popular Prolongada identificada como una variante acorde a realidades en las que el campesinado era el sujeto fundamental y, con éste, la posibilidad de instaurar un poder revolucionario en las zonas liberadas para, desde allí, avanzara las ciudades ${ }^{21}$. Por detrás de estas posturas se escondían tensiones intestinas que el Cordobazo terminó por resolver.

El PRT - EC intervino en estas polémicas al analizar el rasgo desigual entre regiones dentro del capitalismo argentino sin desprender de ello la posibilidad de un cerco campesino a las ciudades. Señaló la presencia de regiones más desarrolladas (como la pampeana), con mano de obra calificada y mayor nivel de vida. Más allá de poseer una población esencialmente urbana, identificó allí una producción agropecuaria integrada sobre todo por "campesinos medianos y ricos" y casi sin campesinado pobre y proletariado rural, razón por la cual la posibilidad de una crisis se volvía impensada. La presencia de zonas más desfavorables y débiles del capitalismo, como el norte del país, en donde no existían sólidas capas medias y las instituciones se volvían endebles, eran las más pertinentes para el inicio de la lucha armada lo que, a su vez, se justificaba en su nexo continental con Bolivia y Brasil en donde este proceso ya se encontraba abierto ${ }^{22}$.

\section{Al Calor del Cordobazo}

El Cordobazo conmovió al mundo de las izquierdas. Con inmediatez a los sucesos, el PRT - LV se apuró a señalar un cambio en la relación de fuerzas de la clase obrera con respecto al gobierno dado que, tras varios años de retroceso, sta pasó a la ofensiva. Vislumbró que el impacto de la movilización dio inicio a una "situación prerrevolucionaria", identificando cuatro características: la inestabilidad dentro de la burguesía, que empezaba a mostrar disputas internas álgidas; la creciente oposición al gobierno por parte de la pequeña burguesía (como el estudiantado); la predisposición a la lucha del movimiento obrero y la contundencia de sus mtodos; y el surgimiento de una vanguardia estudiantil y obrera ya revolucionaria (o con tendencias a virar hacia esa dirección $)^{23}$. 
El PRT - EC definió al Cordobazo como un estallido popular espontáneo de carácter defensivo que demostró la carencia de una dirección precisa como así también de programa, a la vez, que evidenció el desigual desarrollo entre las diversas regiones del país e incorporó a las luchas políticas los métodos de la resistencia activa y la lucha armada. En contraposición con sus antiguos aliados, señaló que, justamente, la situación prerrevolucionaria había finalizado para ya dar comienzo a un proceso revolucionario, lo que exigía la necesidad de un aparato armado que enfrentara a las fuerzas represivas del régimen en futuros estallidos y no confiar en un "espontaneísmo de las masas”. Según su análisis, la posible repetición de éstos sin un ejército revolucionario los tornaría inocuos ${ }^{24}$.

Política Obrera, en tanto, criticó la idea de espontaneidad argumentando que la movilización cordobesa, si bien careció de una dirección revolucionaria, fue producto de discusiones elaboradas desde hacía dos años por diversos activistas, lo cual quedaba evidenciado en el protagonismo de una nueva vanguardia obrera revolucionaria ${ }^{25}$. Visualizó también una crisis prerrevolucionaria del capitalismo nacional en la que habían sido afectadas las instituciones políticas burguesas, a la vez que identificó una debacle del peronismo, a partir de la hipótesis de ruptura de los activistas obreros con este movimiento ante la capitulación al régimen de sus dirigentes gremiales ${ }^{26}$.

El PCR definió al Cordobazo como un “ensayo" revolucionario sin planificación previa que dejaba en las masas una huella y creaba las condiciones para transformar en sujetos revolucionarios a los partícipes. Una de sus consecuencias habría sido la dinámica de un proletariado que superó a sus direcciones y se organizó mediante comisiones de lucha o comandos de acción directa a la vez que practicaron la democracia obrera mediante asambleas. Aparece aquí la idea de "espontaneidad” en la conformación de grupos de acción que en el propio combate callejero organizaron el enfrentamiento contra la represión. El PCR se proponía privilegiar el trabajo sindical mediante la proletarización de su militancia y el fortalecimiento de las agrupaciones gremiales priorizando la disputa por los cuerpos de delegados y comisiones internas ${ }^{27}$.

Similar planteo expresó Vanguardia Comunista, que le otorgó al Cordobazo rasgos espontáneos al tratarse de una lucha que desbordó los marcos de la movilización sindical y mostró ausencia de dirección unificada. No obstante, a diferencia de posiciones como las del PRT - EC, afirmó que el proceso contó con cierta conducción de los obreros automotrices, metalúrgicos y de Luz y Fuerza, quienes fueron seguidos en la calle por estudiantes y vecinos. Ello daba cuenta de una clase obrera que, aunque mediante un movimiento espontáneo, alcanzaba su madurez política reflejada en el desarrollo de consignas que no peticionaban al gobierno ni exigían cambios de funcionarios, sino que esbozaban un carácter "antidictatorial, antiimperialista y antioligárquico". Desde su análisis, el proceso comenzó como una lucha reivindicativa parcial transformándose en un conflicto contra el carácter represivo de la dictadura y, finalmente, en un combate contra el onganiato. Esta organización otorgó un significado a la violencia en las calles, vislumbrando en el ataque a las propiedades un ejemplo de madurez, más allá de percibir como debilidad la incapacidad de destrucción del aparato represivo ${ }^{28}$.

También el Partido Comunista matizó la idea de espontaneidad. Desde su visión, las acciones obreras y populares de mayo fueron la cúspide de una ola de combates desplegada desde el inicio de la dictadura en todo el país y por diversos motivos, dando inicio a una nueva etapa factible de culminar con su derrocamiento. Para el PC la supervivencia de Onganía se debía a la ausencia de un centro coordinador, lo que dejaba un gobierno malherido que, sin caer, había sido derrotado en sus planes ${ }^{29}$. El Cordobazo se entendió como la corroboración de una tesis sostenida por el partido desde 1962: el "giro a la izquierda de las masas" peronistas y no peronistas. El nacionalismo burgués sería paulatinamente sustituido por el marxismo-leninismo, la idea de colaboración de clases reemplazada por la lucha entre ellas y los conflictos por reivindicaciones inmediatas se vincularían cada vez más con las demandas políticas contra la dictadura ${ }^{30}$.

La mayoría de las organizaciones de izquierda reconocieron no haber desempeñado un papel de peso en la movilización cordobesa. Más allá de tratarse de una expresión pequeña, Política Obrera presentó en sus 
análisis una cierta auto-referencialidad, al identificarse como parte del proceso de politización fabril cordobés mediante la influencia de sus agrupaciones sindicales ${ }^{31}$. La excepción más clara fue el Partido Comunista, atribuyéndose una participación de relieve. Las crónicas posteriores dan cuenta de su labor en la elaboración del paro y en el trabajo de propaganda y agitación tanto por parte de su rama sindical como juvenil como así también la difusión de la propaganda partidaria en los cuarteles cordobeses entre los conscriptos (Córdoba, 1971). En testimonios posteriores se afirmó que el PC tuvo un significativo rol en la preparación de la lucha a través de dirigentes sindicales como Jorge Canelles (de la construcción) (Gilbert, 2009). También sobrevuela la relación que mantenía con el partido Agustín Tosco, referente de Luz y Fuerza y la imagen más representativa de la dirigencia combativa de estos años. Sin estar afiliado a una corriente, desde finales de los años cincuenta, Tosco sostuvo estrechos vínculos con el PC y participó de diversas iniciativas sindicales y políticas impulsadas posteriormente (Camarero, 2011).

En otro orden, un rasgo destacado en algunas organizaciones, como el PCR, fue la perspectiva de incorporación de una gama más amplia de sujetos sociales factibles de asimilar a un proyecto revolucionario. Se destacaba la necesidad de una política hacia el proletariado rural en la búsqueda de forjar una organización sindical en donde ella no existiera y se ponderó el rol del estudiantado para convertirlo en aliado de la clase obrera $^{32}$. El estudiantado fue un componente destacado por todas las organizaciones. No obstante, en el clima engendrado con el ascenso cordobés, la perspectiva de su movilización independiente se revelaba insuficiente. Para el PRT - LV, por ejemplo, era improbable que este movimiento forjara un papel autónomo en la lucha dado que no gozaba de un carácter de clase, por lo que su agitación y movilización sólo poseían perspectivas revolucionarias si lograban ligarse a aquellas del movimiento obrero ${ }^{33}$. También PO encontraba en el estudiantado una orientación difusa, por lo que pugnaba para que éste se imbricase con el enfrentamiento popular callejero anti-dictatorial ${ }^{34}$.

En este aspecto, es particular el caso de Vanguardia Comunista. Sus análisis destacaban en el proletariado el sujeto esencial y maduro del proceso y, en razón de ello, se propuso la organización de "Comisiones de obreros clandestinas" que prepararan la autodefensa para futuras acciones y el impulso de asambleas y reuniones por fábrica para continuar con las medidas. No obstante, subrayó como problemática la ausencia en el conflicto del proletariado rural y el campesinado, alertando que, en la medida en que ello no ocurriera, resultaría imposible que la violencia acaecida en las ciudades revirtiera en una guerra organizada del pueblo ${ }^{35}$.

El PC vislumbró que, más allá de la centralidad de la clase obrera, el anhelado frente anti-dictatorial, precisaría de la articulación entre variados actores como el campesinado, el movimiento estudiantil, los partidos políticos y los intelectuales y, en ese esquema, era una tarea del partido encontrar puntos de coincidencia que permitieran confluir ${ }^{36}$. También era notable la primacía que esta organización otorgó a la militancia dentro de las FF.AA. Se sostenía la posibilidad de que, por intermedio de su intervención, se abriera dentro de la esfera castrense una corriente de pensamiento divergente a aquellas identificadas con el nacionalismo, el social-cristianismo y las variantes peronistas ${ }^{37}$. Se trataba de una línea que se consolidaría con los llamados a convergencias cívico-militares (Campione, 2005; Casola, 2010).

Las izquierdas también focalizaron sus análisis no sólo en la conflictividad social sino también en las contradicciones y disputas identificadas en el seno de la burguesía y del aparato estatal. El PRT - LV, identificó una tensión entre la tradicional burguesía nacional, industrial y agro-ganadera (que reivindicaba un crecimiento ligado al mercado mundial) y aquella que propugnaba un desarrollo "neocapitalista" (sosteniendo la combinación entre la burguesía nacional y las inversiones imperialistas). Dentro de esta última facción identificó a las tendencias desarrollistas y señaló la existencia de una corriente que consideraba decisivo garantizar una moneda estable y la libertad de inversión y comercio absoluto de los capitales extranjeros ${ }^{38}$.

Otros grupos también identificaban los sectores que dividían a las clases dominantes. El PCR distinguió tres realidades. La tendencia "eficientista" que aspiraba a privilegiar la producción para el mercado mundial 
y mantener al país como "satélite" de los grandes monopolios internacionales asociando a ellos a la gran burguesía argentina; el sector "desarrollista" que pretendía impulsar la industria y los servicios básicos sobre la base de la sustitución de importaciones pero concediendo todo tipo de facilidades al capital extranjero para atraerlo al país y, finalmente, una propuesta "nacionalista" sostenida por propietarios industriales y rurales que impulsaban la lógica de las nacionalizaciones limitadas ${ }^{39}$. Vanguardia Comunista encontraba una agudización de las luchas internas de las clases dominantes pero simplificó la dicotomía entre el "desarrollismo" de los monopolios norteamericanos que buscaba superar la crisis mediante una apertura democrática y un "ala gorila liberal" que no pretendía ninguna concesión y aspiraba a una economía con la menor regulación estatal posible ${ }^{40}$.

El Cordobazo generó en las izquierdas la reafirmación de ciertas estrategias y modos de intervención, o bien, la resolución de oscilaciones y la elección de un camino a continuar de un modo más definido. El PRT $\mathrm{LV}$, por ejemplo, pronosticó que proseguiría el ascenso del movimiento obrero y el surgimiento de una nueva vanguardia y que este fenómeno provocaría nuevas formas de organización como las coordinadoras obreroestudiantiles o barriales. En esta perspectiva, propuso profundizar la disputa por los organismos de base del movimiento obrero para transformarlos en herramientas revolucionarias. Así, el fortalecimiento partidario se hallaba inherentemente ligado a su influencia sobre la clase trabajadora y sus organismos ${ }^{41}$.

El PRT - EC prevenía contra toda ilusión sobre la espontaneidad de las masas y la vía insurreccional para la toma del poder. Rechazaba la idea de que las movilizaciones se desligaran de la necesidad de creación de un ejército revolucionario y aseveraba que, aún cuando el estallido de mayo hubiera tenido un carácter insurreccional consciente, sus posibilidades de éxito se hubieran visto limitadas por la ausencia de un partido que actuara como dirección política y de un ejército revolucionario capaz de derrotar a las fuerzas militares del capitalismo. En ese sentido, la tarea central que se avecinaba no era la expectativa por la llegada de nuevos estallidos insurreccionales sino la construcción de ese insumo militar que permitiera la toma del poder y cuya carencia en Córdoba fue la causa de la debilidad y los límites del proceso ${ }^{42}$. Se trataba de preparar la guerra revolucionaria en respuesta a las necesidades de la lucha de clases ${ }^{43}$.

Política Obrera polemizó, indirectamente, con aquellas posiciones denominadas “foquistas" cuestionando que los límites de la rebelión hubieran obedecido a la falta de preparación militar. En un planteo que invertía los argumentos del PRT - EC, sostuvo que la lucha de masas no esperaba la constitución de una dirección para manifestarse políticamente, sino que, por el contrario, son estos hechos los que preparaban el terreno para el surgimiento de una vanguardia revolucionaria. Afirmaba que la conciencia insurreccional nacía del propio movimiento de masas y no sería importada por grupos aislados de composición pequeño-burguesa. Sostuvo, a la vez, que la carencia de armamento obrero no fue la debilidad del movimiento sino el aislamiento del proletariado cordobés con relación al resto del país. De allí la reafirmación en torno a la necesidad de construcción de un partido obrero revolucionario y la consigna de elecciones libres sin proscripciones y convocatoria a una Asamblea Constituyente soberana ${ }^{44}$.

El PRT - EC interpeló públicamente al PCR. La tendencia liderada por los Santucho ponderó que esta organización concibiera la lucha armada como perspectiva pero le cuestionó que ella fuera percibida como la culminación de una insurrección popular dirigida por un partido revolucionario (o bien, como la aplicación de métodos armados de defensa espontáneamente establecidos por los propios obreros) y no como parte de una guerra prolongada con acciones de guerrilla urbanas y rurales combinadas, que derrotaran al ejército profesional y a las instituciones de la burguesía, reemplazándolas por organismos populares con sostén del ejército del pueblo ${ }^{45}$. Con perspectivas divergentes, el PC también se expidió en estas polémicas. En primer lugar, deslindándose del mote de "reformista" que parte de la izquierda le atribuía al sostener la importancia de impulsar reivindicaciones inmediatas como una táctica que permitiera vincular éstas con la lucha antidictatorial. En otro orden, defendió la autodefensa como respuesta a la represión, en oposición a 
las premisas "aventureras" de expresiones de "ultraizquierda y guerrilleras" que proponían caminos cortos practicados al margen de las masas ${ }^{46}$.

En otro aspecto, el Cordobazo fue un disparador que permitió reorientar ciertos posicionamientos no carentes de contradicciones. El caso más notorio se produjo en el interior del PCR, donde coexistían tres posiciones divergentes. Una corriente insurreccionalista privilegiaba la construcción partidaria, el desarrollo de frentes de masas, la realización de propaganda no armada y la preocupación por la cuestión militar supeditada al inicio de una insurrección encabezada por la clase obrera; una segunda línea defendía el insurreccionalismo pero no desdeñaba las acciones armadas de propaganda como un acicate de la conciencia revolucionaria; y, finalmente, una tendencia vinculada al paradigma subsidiario de la Revolución cubana que vislumbraba la necesidad del accionar armado con anterioridad a la insurrección (Lissandrello, 2013; Rupar, 2016). El Cordobazo clarificó la línea del PCR. En sus balances, destacó como aspecto positivo que las masas incorporaran a su lucha acciones violentas contra la dictadura, pero sostuvo la necesidad de que estas se insertaran en la perspectiva de la insurrección armada de todo el pueblo. Desde este enfoque, el proceso de conflictividad abierto podría llevar al movimiento obrero al cansancio y al desgaste y, por ello, resultaba ineludible una construcción partidaria que hegemonizara la lucha armada antidictatorial, preparando y encabezando esa insurrección a través de la preparación militar propia y de las masas ${ }^{47}$.

Este planteo llevó al PCR a polemizar con el PRT - EC, al sostener que existía una diferencia entre el tipo de insurrección defendida y la noción de guerra prolongada de guerrillas urbanas o campesinas que, en el fondo, escondía una división entre la hegemonía proletaria o pequeño-burguesa de la dirección. Así, el PCR intentaba no provocar una división entre el trabajo político y el militar atribuyéndole a expresiones como la santuchista la postergación de la gestación de un partido revolucionario bajo el pretexto de la carencia de un ejército. Advirtió la importancia del predominio de lo político por sobre lo militar y la necesidad de evitar el error de pasar a una etapa superior de primacía de la lucha armada dando lugar a la exposición ante el enemigo ${ }^{48}$.

En cierto punto, también para Vanguardia Comunista el proceso cordobés significó un impacto en sus elaboraciones conceptuales y definiciones. La tensión entre una militancia revolucionaria con eje en el proletariado y la premisa de consolidar un trabajo en el campo para luego cercar la ciudad se reveló difícil de resolver. La búsqueda de una integración de estas alternativas teórico-prácticas se pretendió sustanciar a través de perspectivas tales como la adhesión a la idea de Guerra Popular Prolongada, pero con un privilegio por aquellas zonas que tuvieran como mano de obra a los obreros rurales de cultivos como el azúcar, la madera o el tabaco (Soto, 2004). Mayo de 1969 provocó desconcierto en la organización hasta el punto de dilatar la realización de su primer congreso partidario el que, finalmente, tuvo lugar en 1971. Tras el Cordobazo surgió una autocrítica, esgrimiendo que se había sostenido la expectativa de un comienzo de la guerra popular surgida de la propia lucha de masas. Como reorientación, afirmó que el inicio de la guerra sería producto de una combinación entre la lucha espontánea y las iniciativas del partido en su rol dirigente. En diferencias con el PRT - EC, aseveró que tales iniciativas no debían recaer en "acciones atrevidas de agitación y terror" a modo de propaganda armada, pues ello supondría desplazar el trabajo de movilización política y económica de las masas subestimando al partido como ideólogo y dirección de la lucha ${ }^{49}$.

\section{Después del Cordobazo}

¿Cómo analizaron las izquierdas al Cordobazo habiendo transcurrido un tiempo prudencial del suceso, es decir, con la ventaja de contar con la perspectiva de cierta distancia histórica? Tanto los días finales del agitado 1969 como su primer aniversario en 1970 fueron momentos propicios para forjar balances sistemáticos a la luz de un contexto en el que se hallaban vigentes los motivos que originaron la convulsión, pero en un marco de notorio incremento de la conflictividad y la crisis política. El levantamiento cordobésbrió un ciclo de 
protestas en el país que, partiendo de reivindicaciones locales, pusieron en tela de juicio al régimen militar y contaron con el protagonismo de amplios sectores.

El PRT - LV englobó esta sucesión de estallidos regionales en la categoría de "semi-insurrecciones" que incluyeron el enfrentamiento directo de los obreros y estudiantes contra las fuerzas policiales pero, a la vez, carecieron de una dirección que supiera organizar a las masas para golpear en los puntos neurálgicos ${ }^{50}$. Culminando 1969 caracterizó la continuidad de la situación prerrevolucionaria, pero identificando la presencia de dos obstáculos que impedían dar por finalizada la experiencia de Onganía: el desnivel entre las luchas del interior y Buenos Aires y el problema de la dirección obrera, es decir, el control de los sindicatos por una burocracia que no había sido reemplazada por una nueva vanguardia que aún presentaba rasgos de inexperiencia, atomización y espontaneísmo. A ello se agregaba la ausencia de un partido revolucionario de peso que permitiera superar la desorganización del activismo y resolver el problema de dirección ${ }^{51}$.

En tanto, Política Obrera evaluó que, habiendo transcurrido un año del Cordobazo, el país había ingresado en un período de guerra civil entre el proletariado y la burguesía en el que la politización de las masas ya no podría frenarse por medio de un intervencionismo estatal conciliador ${ }^{52}$. En contraposición, el análisis del PRT - EC dio cuenta de una perspectiva con matices al identificar, por un lado, la maduración de la lucha de clases en el país desde 1969 pero, al mismo tiempo, la idea de una ausencia de victorias para los trabajadores dada su imposibilidad de superar la tendencia al "espontaneísmo", las demandas meramente económicas y la incapacidad de vislumbrar como necesidad la construcción de un partido revolucionario ${ }^{53}$.

El PCR afirmó que la crisis abierta por el Cordobazo no se encontraba resuelta dado que tanto la política económica de la dictadura como la universitaria operaban como estimulantes de inestabilidad constante, a lo que se agregaba una cada vez mayor división dentro de las FF.AA. Este partido realizó una comparación entre la situación existente tras un año del fenómeno de Córdoba aseverando que se estaba ante un avance porque ya era factible vislumbrar la influencia que, sobre el proletariado, gozaba su organización en detrimento de "corrientes populistas". En otro orden, identificó como rasgos superadores la tendencia al enfrentamiento directo y la utilización de formas elevadas de lucha de clases como las ocupaciones de fábrica; el surgimiento de nuevas direcciones desde las bases; la avidez por el debate político a través de las asambleas en los lugares de trabajo; la ruptura de los marcos gremiales que permitía movilizar al proletariado en apoyo a los estudiantes y el surgimiento de agrupaciones clasistas que enfrentaban a los jerarcas sindicales. También visualizó un avance en el movimiento estudiantil al cobrar sus luchas un creciente tono antidictatorial y antiimperialista ${ }^{54}$.

En un registro divergente se hallaron los planteos de Vanguardia Comunista. Como rémora de caracterizaciones antes vertidas, analizó que en ciudades como Córdoba el proletariado era más compacto y que las fuerzas subjetivas de la revolución poseían mayor peso. Ello daba como resultado la concentración de la vanguardia proletaria y la necesidad partidaria de privilegiar su inserción en dichas regiones. No obstante, recuperaba la noción en torno a la presencia de "zonas críticas" del capitalismo en provincias como Tucumán o Chaco en las que los grupos dominantes (como la oligarquía o los monopolios) no podrían desviar o amortiguar la lucha popular por intermedio de concesiones, por lo que podrían transformarse en eslabones débiles en la medida en que comenzara una organización del proletariado junto a una mayor presencia de un partido revolucionario. En estas regiones la organización debía concentrar sus fuerzas en vistas a forjar una alianza obrero-campesina que permitiera iniciar la guerra revolucionaria ${ }^{55}$.

En lo que respecta al PC, el aniversario del Cordobazo lo llevó a afirmar que éste modificó el panorama político y marcó un quiebre en el país ante el ascenso general de la lucha de masas y la descomposición de la dictadura. Para el partido, mayo de 1969 avaló la justeza de sus posicionamientos en cuanto al debate con las organizaciones político-militares, dado que demostraba el protagonismo de la clase obrera como sujeto, la posibilidad de transformación de consignas mínimas en planteos anti-dictatoriales y la transición de acciones gremiales en una insurrección popular ${ }^{56}$. Los sucesos posteriores le sirvieron para desarrollar y justificar su hipótesis de "giro a la izquierda" de las masas, identificado en ciertas prácticas (la masificación de los métodos 
callejeros, la ocupación de barrios en el marco de los paros activos, la toma de fábricas o la frecuente realización de asambleas en los sitios de trabajo) y, en términos ideológicos, en el desprestigio de las dirigencias sindicales "de derecha" del peronismo (Córdoba, 1971).

Desde principios de los años setenta se observaron importantes cambios en las metodologías de confrontación de la clase obrera a partir de la creciente demanda de autonomía y democracia de base en las estructuras sindicales. Ello se expresó en medidas de confrontación directas y radicales, tales como las ocupaciones de fábricas con toma de rehenes (Gordillo, 2003). El proceso no pasó por alto para las izquierdas. Éste fue caracterizado por el PRT - LV como el inicio de un cambio de las formas organizativas. Según su análisis, ello podía desembocar en la intensificación de los conflictos parciales defensivos con el surgimiento de nuevas formas organizativas que se combinarían con las ya tradicionales ${ }^{57}$. A la vez, destacó que, tras cumplirse un año, la protesta comenzaba a extenderse hacia Buenos Aires en rubros como los bancarios, telefónicos o docentes lo que reflejaba la radicalización de la pequeña burguesía. La conflictividad de Buenos Aires fue analizada como un fenómeno de características menos explosivas que el proceso cordobés, pero más sólido y continúo pues el movimiento obrero logró consolidarse con la conquista de pequeños objetivos ${ }^{58}$.

Política Obrera reafirmó la idea de conciencia y politización de las masas, fundamentalmente en el interior del país, sosteniendo que la clase obrera no se desviaría de su camino hacia la independencia política con respecto a las vertientes de la burguesía y de las conducciones burocratizadas. Identificó en el movimiento de masas una tendencia irreversible en su "desperonización" en el camino hacia un socialismo revolucionario. En contraposición al PRT - LV, PO encontró en Buenos Aires una situación de rezago aún problemática ${ }^{59}$. En una línea similar, el PRT - EC reflexionó que, desde el Cordobazo, la clase obrera comprendió que los tradicionales aparatos sindicales crecieron a sus expensas bajo la tolerancia de la burguesía y adaptados el régimen capitalista. De ese modo, identificó la existencia de un fuerte repudio a un tipo de dirigente que ya no gozaba de las posibilidades de maniobra de antaño permitiéndoles confundir a los trabajadores y orientarlos hacia el camino de la colaboración de clases. La muerte de Vandor sintetizaba el fin de una etapa de dominio de la burocracia sindical y de su política ${ }^{60}$.

Más notorio fue el cambio en los posicionamientos de Vanguardia Comunista y ello pesó en la visualización del sujeto revolucionario. Destacó la necesidad de construcción del partido dentro de una perspectiva de inserción en la clase obrera y, con esa premisa, en 1970 su Comité Central se mudó a Córdoba para acompañar de cerca los hechos provinciales. Con el tiempo, alcanzó mayor injerencia en conflictos de trascendencia como, por ejemplo, en el SITRAC-SITRAM. Sin perder nociones provenientes de las anteriores etapas, se produjo el abandono paulatino de aquella idea que sostenía que la revolución argentina tendría al campo como su base (Soto, 2004; Rupar, 2016).

La crisis acelerada del régimen político posibilitó a las izquierdas proyectar diversas perspectivas. La presentada por el Partido Comunista tuvo rasgos distintivos. Su planteo recayó en la necesidad de derrocamiento del onganiato a través de la acción de masas y la constitución de un nuevo tipo de gobierno provisional de amplia coalición en su reemplazo, en el que participaran diversas fuerzas anti-dictatoriales y democráticas. Se vislumbró la convocatoria a una Asamblea Constituyente como paso preciso para acelerar las condiciones para una revolución democrática, agraria y antiimperialista ${ }^{61}$. Como resultado de la idea de conformación de un centro político que dirigiera al conjunto de las luchas, el PC avanzó en la posterior difusión del llamado Encuentro Nacional de los Argentinos (ENA), al que definió como un "embrión de poder popular" (Córdoba, 1971).

El PRT - LV pronosticó la posibilidad de un recambio dentro del sistema consistente en la búsqueda de una salida democrática por parte de diversas facciones de la burguesía y el ejército. Esto le valió una polémica con aquellas organizaciones que, ante un hipotético devenir electoral, rechazaban todo tipo de participación por esa vía. Su argumento recayó en no dejar libradas las demandas de elecciones libres y democráticas a "organizaciones burguesas o burocráticas" sino tomarlas como propias y ligarlas a la necesidad de la 
movilización para efectivizarlas. Pronosticó que, ante la continuidad del ascenso obrero y de su radicalización, la burguesía se vería finalmente obligada a utilizar el recurso de la vuelta del peronismo como una estrategia de apaciguamiento de los ánimos ${ }^{62}$. En la adopción de esta línea ante un escenario electoral, esta organización se diferenció de alternativas en boga como el ENA, caracterizado como un intento del PC de emular a la Unidad Popular de Chile, con la diferencia de carecer de la participación obrera y aspirar a una alianza con sectores de la burguesía considerados progresivos ${ }^{63}$.

Para Política Obrera, se abría un período en el que se combinarían las luchas políticas con las económicas a la par de esporádicos levantamientos. Se propuso la gestación de un programa revolucionario que contemplara al conjunto de las reivindicaciones inmediatas, sindicales o económicas, en combinación con consignas políticas directas pugnando por unificar a todas ellas con los métodos de la acción de masas y de la guerra civil revolucionaria, como la democracia obrera y la ocupación fabril defendida con piquetes de huelga armados ${ }^{64}$. Meses después, PO impulsó la convocatoria a un Frente Único Antiimperialista como herramienta de las luchas del proletariado para superar a las direcciones peronistas, nacionalistas y a la burocracia sindical ${ }^{65}$.

En el caso del PRT - EC, el derrotero posterior a mayo de 1969 sirvió como reafirmación de premisas. Así, destacó el papel jugado por la organización en la educación de la vanguardia movilizada para que, a partir de los problemas mínimos, comenzara a practicar el ejercicio de la violencia organizada y de la lucha armada. Caracterizó como uno de los aspectos más positivos del Cordobazo la consagración de la violencia como una forma de lucha legítima e inevitable por parte de sectores cada vez más amplios que simpatizaban con las acciones realizadas ${ }^{66}$. Bajo estos presupuestos aceleró los tiempos de formación de un ejército revolucionario y, tras la realización de su V Congreso en 1970, formalizó esta línea con la creación del Ejército Revolucionario del Pueblo (ERP), una herramienta subsidiaria del partido que posibilitara la preparación y el inicio de la guerra revolucionaria ${ }^{67}$.

Por último, el aniversario del Cordobazo fue, para el PCR, la reafirmación de su postura insurreccionalista y de la ponderación del proletariado. Ello no se debió sólo al balance realizado al cumplirse un año del acontecimiento sino más bien al desarrollo de un conflicto en esta misma provincia en la fábrica Perdriel, en la que el partido tuvo un lugar de dirección. Este papel resultó fundamental para subrayar la importancia de una estrategia insurreccional y cerrar los debates internos. En este escenario, entabló un debate público con las FAL, organización armada que poseía militantes desprendidos del PCR. Se criticaba al grupo por su política voluntarista consistente en desarrollar acciones militares sin tener inserción entre los sectores movilizados. Argumentó que el "terrorismo urbano" invertía la lógica: en lugar de ganar a las masas para que ellas desarrollaran la guerra revolucionaria, se la practicaba para que aquellas fueran espectadoras de un combate que no protagonizaban. Esta discusión se sintetizó en la consigna "Más vale un Perdriel que cien secuestros", que habilitó un cierre de las tensiones internas ${ }^{68}$. Para el orientador de este partido, existieron dos hechos que "salvaron" al PCR de caer en la lógica de militarismo urbano: el Cordobazo y la toma de Perdriel (Brega, 2008).

Históricamente, las revueltas, los levantamientos populares y las grandes manifestaciones de protesta, fueron referencias esenciales para las izquierdas en la Argentina y en todo el mundo. Los imaginarios, las simbologías y el sistema de representación de estas culturas políticas siempre estuvieron expectantes a la existencia o a la esperanza de este tipo de eventos. Lo mismo había ocurrido con la Semana Roja de 1909 y las huelgas del Centenario, la Semana Trágica de 1919, las huelgas de la construcción y general de 1936, el 17 de octubre de 1945 o algunos de los violentos conflictos de la época de la Resistencia en el posperonismo, entre otros. El Cordobazo tuvo la especificidad de que, a pesar de haber sido reconocido y saludado por las izquierdas 
como un extraordinario acontecimiento de lucha de la clase obrera y el pueblo, no contó con la participación orgánica y destacada de aquellas, más allá de algunas presencias puntuales. Al mismo tiempo, en corrientes que hacían hincapié en la previsión de los fenómenos de protesta, lo notable fue la sorpresa que alcanzó a casi todas ellas.

Si las jornadas de Córdoba provocaron un sentimiento inicial de perplejidad ante la profundidad de los hechos, el paso siguiente fue la creciente excitación por las nuevas perspectivas que se creía abría el extraordinario acontecimiento. El fin de un ciclo de repliegue de los trabajadores, el deterioro decisivo en las condiciones de dominación del régimen militar, el inicio de una situación prerrevolucionariao revolucionaria, la amenaza que se cerniría sobre el tradicional control de la burocracia sindical, la aparición de una vanguardia obrera y estudiantil mayormente madura, la radicalización ideológica y política de nuevas camadas de activismo militante, el fortalecimiento de alas revolucionarias del movimiento obrero, la apertura de una dinámica más propicia para las acciones armadas, entre otros elementos, todos ellos fueron apuntados en las primeras argumentaciones. Como hemos visto, los grupos y partidos de izquierda mostraron la necesidad de presentar balances públicos sobre el significado de mayo de 1969 y sus proyecciones. En algunas organizaciones, el estallido generó desconcierto y debates que atravesaron a su militancia y definieron orientaciones y estrategias de intervención. En definitiva, el Cordobazo marcó el inicio de otro período en la historia de las izquierdas argentinas.

\section{BiBLIOGRAFÍA}

AA.VV. (1969) Vigencia del leninismo hoy y en la Argentina. Jornadas leninistas realizadas durante los días 13 y 14 de diciembre de 1969. Bs. As.: Editorial Anteo.

Balvé, B. et al. (2006). Lucha de calles, lucha de clases. Elementos para su análisis (Córdoba, 1971-1969). Buenos Aires: RyR-CICSO.

Brega. J. (2008) ¿Ha muerto el comunismo? El maoismo en la Argentina. Conversaciones con Otto Vargas. Buenos Aires: Ágora.

Brennan, J. (2015). El Cordobazo. Las guerras obreras en Córdoba, 1955-1976. Buenos Aires: Waldhuter.

Brenann, J., y Gordillo, M. (2008). Córdoba rebelde. El Cordobazo, el clasismo y la movilización social. Buenos Aires: De la Campana.

Bonvillani, P. (2015). Unidad contra la dictadura 'corporativa-fascista': algunas lecturas del Partido Comunista Argentino sobre el golpe de Estado de 1966. Izquierdas, 22, 110-132.

Califa, J. S. (2015). Del Partido Comunista al Partido Comunista Comité Nacional de Recuperación Revolucionaria en la Argentina de los años sesenta. Una escisión con marca universitaria. Izquierdas, 24, 173-204.

Camarero, H. (2011). Lucha sindical y compromiso político: algunas observaciones sobre Agustín Tosco y su militancia de izquierda. En A. Tosco, Textos reunidos II. 1972-1975. (pp. 41-59). Córdoba: Editorial de la Universidad Nacional de Córdoba.

Camarero, H. (2014). Tras las huellas de una ilusión: el Partido Comunista argentino y sus planteos del Frente Democrático Nacional (1955-1963). Archivos de historia del movimiento obrero y la izquierda, 3(5), 31-50.

Campione, D. (2005). Hacia la convergencia cívico-militar. El Partido Comunista 1955-1976. Herramienta, IX(29), 141-164.

Carnovale, V. (2011). Los combatientes. Historia del PRT-ERP. Buenos Aires: Siglo XXI.

Casola, N. (2010). El Partido Comunista Argentino y el golpe militar de 1976: las raíces históricas de la convergencia cívico-militar. Izquierdas, 6, 1-15.

Cavarozzi, M. (2006). Autoritarismo y democracia (1955-1996). Buenos Aires: Ariel.

Celentano, A. (2014). Maoísmo y nueva izquierda. La formación de Vanguardia Comunista y el problema de la construcción del partido revolucionario entre 1969 y 1969. En M. C. Tortti (Dir.), La nueva izquierda argentina (1955-1976). Socialismo, peronismo y revolución (pp. 83-109). Rosario: Prohistoria. 
Coggiola, O. (2006). Historia del trotskismo en Argentina y América Latina. Buenos Aires: Ediciones RyR.

Córdoba, A. (1971). El Cordobazo. Apuntes de un combatiente. Córdoba: Anteo.

Gilbert, I. (2009). La Fede. Alistándose para la revolución. La Federación Juvenil Comunista, 1921-2005. Buenos Aires: Sudamericana.

González, E. (Coord.) (1999). El trotskismo obrero e internacionalista en la Argentina. Tomo 3: Palabra Obrera, el PRT y la Revolución Cubana. Volumen 2 (1963-1969). Buenos Aires: Antídoto.

Gordillo, M. (1991). Los prolegómenos del Cordobazo: Los sindicatos líderes de Córdoba dentro de la estructura de poder sindical. Desarrollo Económico, 31(122), 163-187.

Gordillo, M. (2003). Protesta, rebelión y movilización: de la resistencia a la lucha armada, 1955-1973. En D. James (Dir.). Nueva Historia Argentina. Tomo IX: Violencia, proscripción y autoritarismo (1955-1976). Buenos Aires: Sudamericana.

James, D. (2003). Sindicatos, burócratas y movilización. En D. James (Dir.). Nueva Historia Argentina. Tomo IX: Violencia, proscripción y autoritarismo (1955-1976) (pp. 117-167). Buenos Aires: Sudamericana.

Lissandrello, G (2013). El Partido Comunista Revolucionario (PCR) y la discusión estratégica en los setenta (1967-1972). En Actas X Jornadas de Sociología de la UBA.

Mangiantini, M. (2018). Itinerarios Militantes. Del Partido Revolucionario de los Trabajadores al Partido Socialista de los Trabajadores (1965-1976). Buenos Aires: Colección Archivos/Imago Mundi.

O'Donnell, G. (1982). El estado burocrático autoritario. Triunfos, derrotas y crisis. Buenos Aires: Editorial de Belgrano.

PCR (2005). Documentos aprobadospor el PCR a partir desu $1^{\circ}$ Congreso, diciembre de 1969, hasta su $2^{\circ}$ Congreso, abril de 1972. Buenos Aires: Editorial Ágora

Portantiero, J. C. (1996). Economía y política en la crisis argentina (1958-1973). En W. Ansaldi, y J. L. Moreno (Comps.). Estado y sociedad en el pensamiento nacional. (pp. 301-346). Buenos Aires: Cántaro.

Pozzi, P. (2004). Por las sendas argentinas. El PRT-ERP, la guerrilla marxista. Buenos Aires: Imago Mundi.

Pozzi, P., y Schneider, A. (2000). Los setentistas. Izquierda y clase obrera: 1969-1976. Buenos Aires: Eudeba.

Castillo, C., y Raimundo, M. (Comps.) (2012). El 69 platense. Luchas obreras, conflictos estudiantiles y militancia de izquierda en La Plata, Berisso y Ensenada durante la Revolución Argentina. Buenos Aires: Estudios Sociológicos Editora.

Rupar, B. (2016). La emergencia del maoismo en Argentina: una aproximación a través de Vanguardia Comunista y el Partido Comunista Revolucionario (Tesis de maestría, Universidade Federal Fluminense).

Rupar, B. (2017). El rol de la Revolución Cultural China en el maoísmo argentino. Leste Vermelho, 3(1), 355-375.

Schneider, A. (2005). Los compañeros. Trabajadores, izquierda y peronismo (1955-1973). Buenos Aires: Imago Mundi. Soto, A. (2004). Vidas y Luchas de Vanguardia Comunista, (Tomo I). Buenos Aires: Nuevos Tiempos.

Tortti, M. C. (1999). Izquierda y 'nueva izquierda' en la Argentina. El caso del Partido Comunista. Sociohistórica, 6, 221-232.

Tortti, M. C. (2014). La nueva izquierda argentina (1955-1976). Socialismo, peronismo y revolución. Rosario: Prohistoria.

Weisz, E. (2004). Nueva Izquierda e Izquierda Tradicional. Buenos Aires: Ediciones del CCC.

\section{Notas}

1. “Asegurar el paro nacional en la base a través de asambleas y coordinadoras", en: Nuestra Palabra [NP], N 986, 27-05-1969, p. 7; “La tarea inmediata”, en: $N P, \mathrm{~N}^{\circ} 982,29-04-1969$, p. 1.

2. "Marchar al paro nacional contra la dictadura asesina y su amo Rockefeller", en: NP, $N^{\circ}$ 986, 27-05-1969, p. 1.

3. "Las consignas militares y paramilitares para la nueva etapa", Congreso Nacional del PRT-LV, 1970.

4. "El movimiento obrero argentino. Situación y perspectivas", en: La Verdad[LV], No 176, 14-04-1969, p. 3 y 6.

5. "Córdoba marca el camino: Por un inmediato paro nacional", en: Política Obrera[PO], Año III, No 51, 21-05-1969, pp. 1-9. 
6. "Onganía: Mito frustrado", en: El Combatiente[EC]. Año II, N² 28, 07-05-1969, pp. 3-4.

7. "Córdoba marca el camino...", Op. Cit.

8. "Paro obrero y estudiantil contra la dictadura", en: $L V$, No 182, 26-05-1969, p. 1.

9. “La orden de Perón”, Nueva Hora, $\mathrm{N}^{\circ} 18$, lera quincena dic 1968 (PCR, 2005).

10. “Quién debe dirigir la lucha antidictatorial?” en: No Transar, $\mathrm{N}^{\circ} 78$, Mayo de 1969, pp. 2-4.

11. “Tesis para el XIII Congreso", PC (CNRR), Buenos Aires, noviembre de 1968 (PCR, 2005).

12. "Proyecto de Resolución sobre la Situación Nacional", VC, Octubre de 1968.

13. "Como defenderse de la represión", en: $L V$, No 182, 26-05-1969, p. 6.

14. "Paro obrero-estudiantil conjunto", en: $P O$, Año III, $N^{\circ}$ 51, 21-05-1969, pp. 9-11.

15. "Llamamiento del Partido Comunista", en: $N P, \mathrm{~N}^{\circ} 986,27-05-1969$, p. 1.

16. "Derrotar la dictadura de los monopolios con el Frente Democrático Nacional", XIII Congreso Nacional del Partido Comunista, en: Nueva Era, $\mathrm{N}^{\circ} 1$ al 5, 1969, Tomo 1, pp. 225-234

17. "Los comunistas revolucionarios ante la actual situación política nacional e internacional", Informe del Comité Nacional, Partido Comunista (CNRR), noviembre de 1968 (PCR, 2005).

18. "Frente único contra la dictadura militar pro-yanqui", VC, Ediciones No Transar, 05-07-1966; "Onganía: Mito frustrado", en: $E C$. Año II, N²2, 07-05-1969, pp. 3-4.

19. "Frente a la crisis política impongamos una salida democrática revolucionaria", en: $L V, \mathrm{~N}^{\circ} 181,19-05-1969$, pp. 1-2.

20. "Proyecto de Resolución sobre la Situación Nacional", VC, Octubre de 1968; "Resolución del CC de Vanguardia Comunista", Cuadernos Rojos $\mathrm{N}^{\circ}$ 2, septiembre 1970.

21. "Tesis para el XIII Congreso", Op. Cit.

22. "Norte Argentino: eslabón débil del capitalismo", en: EC. Año II, N 28, 07-05-1969, pp. 5-7.

23. "Tesis sobre la situación nacional después de las grandes huelgas generales", Comité Central del PRT-LV, Junio de 1969; "1969. Año del despertar obrero", en: $L V$, № 207, 29-12-1969, pp. 1-7.

24. "Resistencia activa a la dictadura de los monopolios" en: $E C$. Año II, No 30, 11-06-1969, pp. 8-9.

25. "Viva el alzamiento obrero-popular de Córdoba", en: PO, Año 3, No 52, 04-06-1969, pp. 1-5 y 24.

26. "La situación política", en: PO, Año 3, № 52, 04-06-1969, pp. 12-20; "Por una nueva dirección. Congreso de bases", en: $P O$, Año III, $\mathrm{N}^{\circ} 53,26-06-1969$.

27. "Documentos aprobados por el Primer Congreso del Partido Comunista Revolucionario", Córdoba, 11 al 14 de diciembre de 1969 (PCR, 2005).

28. "Circular de la Dirección Nacional sobre la situación nacional y el trabajo partidario", VC, Septiembre de 1969; "Hay que seguir luchando", en: No Transar, $\mathrm{N}^{\circ} 79$ Extra, 06-06-1969, pp. 3-4; “Córdoba: el rumbo", en: No Transar, $\mathrm{N}^{\circ} 79$ Extra, 06-06-1969, pp. 5-6.

29. "La lección de las luchas de mayo: ¡Es hora de la unidad nacional contra la dictadura!", en: Nueva Era, $\mathrm{N}^{\circ} 1$ al 5, 1969, Tomo 1, pp. 417-428; "La situación nacional y sus perspectivas" [Gerónimo Arnedo Álvarez. Informe realizado en la reunión del Comité Central los días 22 y 23 de noviembre de 1969], Nueva Era, $\mathrm{N}^{\circ} 6$ al 11, 1969, Tomo 2, pp. 629-655.

30. "Aportes de leninismo al análisis de la realidad nacional y la línea de nuestro partido" [Fernando Nadra] (AAVV, 1969).

31. "Córdoba marca el camino...", Op. Cit.

32. "Documentos aprobados por el Primer Congreso...", Op. Cit.

33. "El movimiento estudiantil y nuestra política", Comité Central del PRT-LV, 1968

34. "Paro obrero-estudiantil conjunto", en: $P O$, Año III, $N^{\circ}$ 51, 21-05-1969, pp. 9-11.

35. "Córdoba: el rumbo", en: No Transar, $\mathrm{N}^{\circ} 79$ Extra, 06-06-1969, pp. 5-6.

36. "Por la unidad del movimiento obrero" [Rubens Iscaro], en: Nueva Era, $\mathrm{N}^{\circ} 1$ al 5, 1969, Tomo 1, pp. 435-445.

37. "La situación en las Fuerzas Armadas y el problema de la autodefensa de masas" [José Sotomayor], en: Nueva Era, N ${ }^{\circ}$ 1 al 5, 1969, Tomo 1, pp. 457-467.

38. "Tesis sobre la situación nacional...", Op. Cit.

39. "Documentos aprobados...", Op. Cit.

40. "Circular de la Dirección Nacional...", Op.Cit.

41. "Original de volante, que deberá imprimir cada zona para el paro lo más rápido posible", Comité Ejecutivo del PRT-LV, 24-09-1969; "Orden del día del C.E. del 21 de junio de 1969", Comité Ejecutivo del PRT-LV, 21-06-1969.

42. "Resistencia activa...", Op. Cit.; "Las movilizaciones populares en todo el país dijeron: Abajo la dictadura de los monopolios", en: $E C$. Año II, No 30, 11-06-1969, pp. 3-7.

43. “iAbajo la dictadura...”, en: EC. Op. Cit.

44. "Viva el alzamiento obrero-popular...", Op. Cit.; "La situación política", Op. Cit.

45. "Carta al PCR", PRT, 20-08-1969.

46. "La lección de las luchas de mayo...”, Op. Cit.; "La situación en las Fuerzas Armadas...", Op. Cit.

47. "Documentos aprobado...", Op. Cit.

48. Ibídem. 
49. “Circular de la Dirección...”, Op. Cit.

50. “Tesis sobre la situación nacional...”, Op. Cit.

51. "1969. Año del despertar obrero", Op. Cit.

52. "Por un nuevo mayo, nacional y definitivo", en: $P O$, Año IV, $N^{\circ} 70,18-05-1970$.

53. “1969: Saldo favorable”, en: $E C$, Año II, No 41, 23-12-1969, pp. 5-10.

54. "Conferencia permanente del PCR", 15 y 16 de agosto de 1970 (PCR, 2005); "Lo nuevo del Mayo 70", en: Nueva Hora, 1ra Quincena de Junio de 1970, N 46, p. 2.

55. "Resoluciones del Comité Central de Vanguardia Comunista publicadas en el Cuaderno Rojo N²", Septiembre de 1970.

56. “A un año de 'El Cordobazo" [Jorge Bergstein], en: Nueva Era, N 1 al 5, 1970, tomo 1, pp. 438-446; “Córdoba espera en la avanzada", en: $N P, \mathrm{~N}^{\circ} 1039,02-06-70, \mathrm{p} .1$.

57. "Las consignas militares y paramilitares...", Op. Cit.

58. "Informe sobre la situación nacional”, Comité Central del PRT-LV, 1970; “1971: Forjemos una dirección para la lucha”, en: $L V$, No 250, 13-01-1971, pp. 1-3.

59. "Por un nuevo mayo, nacional y definitivo", Op. Cit.

60. “1969: Saldo favorable”, Op. Cit.

61. "El setenta", en: $N P, \mathrm{~N}^{\circ} 1018,06-01-70$, p. 8.

62. “Tesis sobre la situación nacional...", V Congreso Nacional del PRT-LV, Op. Cit.

63. "Informe sobre la situación nacional”, Comité Central del PRT-LV, 1970.

64. "Por un nuevo mayo, nacional y definitivo", Op. Cit.

65. "Organizar el Frente Único Antiimperialista”, Resolución del CC de PO (Coggiola, 2006).

66. “1969: Saldo favorable”, Op. Cit.

67. "La guerra en marcha”, en: $E C$, Año III, N 46, 15-08-1969 [error en el original, es 1970]; "Proclama del ERP”, en: EC, No 53, 2० Quincena marzo de 1970, p. 8. [La fecha real es 1971, errónea en la edición original].

68. IKA - Perdriel: un camino y un método, en: Nueva Hora, 1 ra Quincena de Junio de 1970, N 46, pp. 4-5; "Conferencia permanente del PCR", Op. Cit. 